コー検查で腰仙部脊髄髄膜瘤および水頭症の診断がついてい た. 腰仙部脊髄髄膜瘤に対し, 型の如く修復術抢よび脳室腹腔短絡術を行った，皮膚縫合の際に幅 $6 \mathrm{~cm}$ の皮膚欠損で あったが，ネラトンチューブで皮䖉を保護しながら，皮膚欠 損部の両側にナイロン糸をU 字型にかけ， 7 分間牽引，3 分 間弛緩を 4 回繰り返し, 術中に皮膚の伸展を図った。その後, 皮下の undermining を行うこと無しに，皮膚を 2 層縫合し， 手術を終了した，術後，創部癒合は良好であった，考察：春 髄髄膜瘤の修復術において, 脆弱な皮膚を切除すると大きな 皮虚欠損ができることになるが，われわれの施設では従来皮 䖉閉鎖時には広い範囲で undermining したり, 減張切開を加 えたりしていた，今回，術中に皮䖉を間久的に伸展させるこ とで，これらの操作を行わずに創閉鎖できた。皮下組織から の血流を温存できる，皮下に血腫が貯留しにくいなどの利点 があげられ，創部の癒合も良好であった。点としては，皮 膚を伸展させるために手術時間が 30６0 分程度長くなるこ とがあげられる。

\section{6 幼児の割髄症の一例}

大阪府立母子保健総合医療センター脑神経外科 ○山田 淳二 竹本 理

割髄症は脊髄が部分的に分離する先天性の疾患で，二分春 椎の中では春髄脂肪腫や春髄皮膚洞に比べ，非常にまれな先 天奇形である．今回，進行する下肢の変形を主訴とした幼児 の割髄症例を経験したので報告する。

症例は 6 歳女览. 幼少時より左下肢の内反足があり近医整 形外科で通院治療を受けていた。当初は，装具着用などで様 子をみていたが内反足と筋萎縮は緩徐に進行するため当科紹 介となった。

初診時所見では左下肢の短縮と筋萎縮, 内反足を認めた. 感覚障害は明らかではなく, 膀胱直腸障害もなかった。腰仙 髄の MRI 掞よびCT では下位胸髄から尾側方向へ縦に分割さ れた割髄症がみられた。中隔を形成する骨性成分は確認でき なかったが，分割された左側の春髄が尾側で繋留されている と考えられた。術中所見では, 術前評価で確定していた左側 脊髄の終系脂肪腫の他に，仙髄高位で 2 力所において索状物 による繋留所見がみられた。これらの索状物は，左側脊髄の 背側から尾側に向かい硬膜をそれぞれ貫通したのち硬膜外軟 部組織に終わっていた。周辺の脊髄神経根を温存し 3 力所の 慗留解除を行った。術中所見は, 患児の臨床症状と一致し, 本症例を放置した場合，神経障害の進行が予測された。

治療経過を術中ビデオの提示と文献的考察を加えて報告す る.

\section{8. 頖椎変性疾患}

\section{7 頸椎外側塊スクリューと椎弓根スクリュー：当院で の使い分け}

ツカザキ病院脳神経外科

$$
\begin{array}{ll}
\text { ○下川 宣幸 夫 由彦 塚崎 裕司 } \\
\text { 杉野 敏之 浦野裕美子 }
\end{array}
$$

はじめに：当院での外側塊スクリュー（以下 LMS）と椎弓 根スクリュー（以下 PS）の使い分けとその刺入に際しての工 夫を報告する．対象と方法：対象は，2002 年 2 月より 2008 年 3 月までに当院で手術を施行した 39 例である. 27 歳から 90 歳（平均 61.9 歳）に分布し, 男性 33 例, 女性 6 例であっ た．中下位頸椎 LMS を使用した症例は 23 例で，環椎 LMS を使用した症例は 17 例であった。軸椎 PS を使用した症例 は 11 例，中下位頸椎 PS を使用した症例は 6 例であった。全 例 MR angio や CT angio で椎骨動脈の走行や発達程度（頭蓋 内 MRA で collateral の程度も評価している）を検討し，中下 位頸椎に㧍いては LMS を first choice としたが, 外側塊の発 達が悪い症例や外側塊骨折例，椎骨動脈の片側閉塞例（閉塞 側のみ）においてはナビゲーションシステムと透視を併用し， PS 刺入を行った，骨移植は局所骨が不十分であれば，自家腸 骨や HA を使用した。中下位頸椎の固定においては，全例椎 間関節に骨移植を併用した．PS 刺入に扔いて，術前のCTよ り至適スクリュー角度と entry point を計測し，広げられた筋 肉層により内側向きにスクリュー刺入しょうとする力が抗わ れないように，小皮膚切開線を外側に新たに設けて椎体が rotationしないように注意して，刺入する力を加減しながら刺入 した，C6，C7 は外側塊の発達も悪いため, PS や椎弓フック をアンカーとするか, 長めの unicortical screw で LMS を刺入 した，結果：LMS 170 本，PS 56 本は正しい位置に刺入され ており，神経血管損傷や感染の合併症を認めなかった。考 察・結語：症例毎に脳を含めた術前の詳細な画像評価は必須 であり，ナビゲーションシステムや透視を駆使して安全にス クリュー刺入することは重要と考える。

\section{8 椎弓切除術後の C5 palsy 出現に関する検討}

\begin{tabular}{|c|c|c|c|}
\hline ○平松 & 亮 & 田辺 英紀 & 英 賢一郎 \\
\hline 島野 & 裕史 & 安田宗一郎 & 井上 洋人 \\
\hline & 実 & 横山 & 中澤 \\
\hline & 健一 & 近藤 & \\
\hline
\end{tabular}

城山病院 脳・脊髄・神経センター

頸椎へルニアや後縦勒带骨化症などに代表される压迫性頸 髄症に対する治療の基本は保存的加療である。しかし難治性 のもの，さらには生活に支障をきたすような症状の出現を認 めた際には手術適応となる.手術方法としては前方アプロー チもしくは後方アプローチがあり，その手術による合併症と して C5 palsy に代表される上肢運動麻疩がよく知られている. これは 1961 年に Scoville と Stoops が初めて椎弓切除後の合 
併症として術後上肢麻痺を発表したことがきっかけで, 過去 多くの著者が報告されてきた．C5 palsy の出現率は一般的に 約 $5 \%$ と言われているが，予後に関しては良好であるとされ ている. しかし C5 palsy の発生機序としては神経根障害説や 脊髄障害説となどさまざまな説が報告され, 治療法・予防法 についても色々と報告はある。しかしどれも現在確立された ものはなく，多くの矛盾が存在している.

今回この圧迫性頸髄症に対する合併症である C5 palsy に関 して検討を行うべく, 当院で行った頸髄症術後に出現した C5 palsy r retrospective に検討を行った。期間は 2006 年 7 月〜2007 年 9 月までの 14 力月。症例は椎弓形成術 17 例の みに限定し, 出現率は 5.9\%（1/17）であった. C5 palsy 出現 に関して文献的考察を加え検討を行った。

\section{9 頸椎零柱管狭窄症/胸椎黄色勒帯骨化症合併例の 治療}

大津市民病院脳神経外科

○川那辺吉文 頳子丸 稔 湯川 弘之 澤田 真寛

はじめに：歩行障害を主訴とする頸椎脊柱管狭窄症/胸椎黄 色勒帯骨化症の合併症例 6 例について治療経過を報告する.

症例: 頸椎椎弓形成術施行後, 別の日に胸椎片側椎弓切除術 を行った症例が 2 例. 頸椎椎弓形成術と胸椎片側椎弓切除術 を同時に行った症例が 4 例である．同時に手術を行わなかっ た 2 症例は, 頸椎椎弓形成術前に胸椎黄色勒帯骨化症が指摘 されていなかった。頸椎椎弓形成術後に, 歩行障害や下肢痛 が増悪したため, 胸椎の精査を行い, 胸椎黄色勒帯骨化症が 認められ, 胸椎片側椎弓切除術を施行した. 術後症状は改善 したが，歩行訓練等のリハビリテーションを必要とした．同 時に行った 4 例は, 術前に頸椎脊柱管狭窄症と胸椎黄色勒带 骨化症の合併が明らかとなっていた。術後歩行障害は速やか に改善し，リハビリテーションをすることなく，退院された。 結語：上位脊髄疾患が原因と考えられる下肢症状を認め, 頸 椎脊柱管狭窄症とともに, 胸椎黄色勒带骨化症が存在する場 合，両方を同時に手術することは，有効であると考えられる． 頸椎椎弓形成術のみを行った場合, 症状が増悪する可能性が あり, 注意が必要である。

\section{9. 炎症性疾患・他}

\section{0 急速に症状の進行を認めた脊髄葡内病変の一例}

大阪医科大学附属病院 脳神経外科学教室

○矢木 亮吉 山田 佳孝 田村 陽史
黑岩 敏彦

比較的急速に症状が進行した脊髄髄内病変を経験したので 報告する. 症例は 60 歳女性, 両足底部のしびれ感にて発症 し, 発症 5 日後には第 6 胸髄䯚節レベルまで上行. 発症 7 日 目には排便排尿が分からなくなり, 発症 8 日目に他院受診.
尙髄 MRIにて異常を認め紹介となった. 入院時神経学的所見 は第 6 胸髄髄節レベル以下のしびれ感, 触覚低下, 深部知覚 低下を認めるが，運動麻瘦は認めず．两下肢深部腱反射立進， Babinski 反射陽性，排尿障害であった，春髄 MRI では T7レ ベルを中心に T1 強調 等信号, T2 強調 高信号, 淡く造影 を受ける病変を認めた。軸位断では中心部から後索に局在し ており，上下に脊髄空洞は認めず，造影レベルでの脊髄腫大 も認めず．脳 MRI では異常所見は認めなかった．鑑別診断と して脊髄上衣腫, 脊髄星細胞腫, 多発性硬化症が挙げられた。 当初生検手術を検討していたが, 髄液検査を行った結果, 蛋 白質正常, 細胞数 $5 / \mu l$, IgG 正常, 塩基性ミエリン蛋白 2000 $\mathrm{pg} / \mathrm{ml}$ 高值, オリゴクローナルバンド陰性, 細胞診㓌性であっ た. 経過観察としていたが, 発症より 25 病日より徐々に症 状改善傾向となった。第 37 病日に脊髄 MRI 再検査を行った 結果, 造影病変は縮小して抢り, 多発性硬化症の初発と診断 した。多発性硬化症の診断には空間的多発性, 時間的多発性 が必要であるが, 本症例は初発の単発春髄病変であり, 診断 は困難である。文献的考察を加えて報告する。

\section{1 頭蓋内および猆髓内に併発した Inflammatory pseudotumor の一例}

大阪大学医学部脳神経外科

○石原 正浩 岩月 幸一 青木 正典
芳村 憲秦 泉本 修一 吉峰 俊樹

Inflammatory pseudotumor は全身の臓器に発生し, 多くは 良性の病変であるが，中枢神経系での発現は非常に稀である。 症例は 56 歳 男性 $\mathrm{H} 19$ 年 8 月頃より右下肢の筋力低下を自 覚し近医受診した。頭部 CT で左側脳室三角部周囲に広範囲 な浮腫を伴う $2 \mathrm{~cm}$ 大の淡い High density areaを認めた. 腫 瘍性病変と考え，開頭腫瘍摘出術を施行した。病理所見はリ ンパ球，形質細胞などの炎症性細胞と間質の強い線維化によ る線維性組織であり, 異型的な所見がなくポリクローナルで あることから炎症性反応性病変である Inflammatory pseudotumor と考えられた。術後一時歩行障害の改善を認めたが, 再 度右下肢の筋力低下を認め, さらに左下肢の筋力低下を認め るようになった。脊髄 MRI を施行したところ, C7/Th1 に T1 iso intensity, T2 low intensity, ガドリニウムで均一に造 影される䯣内病変を認めたため, 脊䯣腫瘍摘出術を施行した。 腫瘍は頭部病変と同様に Inflammatory pseudotumor であった。 Inflammatory pseudotumor の脊髄内発症例は現在 16 例報告さ れているが，頭蓋内抢よび蓨髄の両方に病変を認めるものは 1 例のみであった. 我々は Inflammatory pseudotumor の頭蓋 内, 脊䯣併発例を経験した。 その放射線学的, また, 病理学 的所見につき考察する. 